\title{
$\mathrm{Al}-\mathrm{Mg}$ 合金に対するインデンテーションの荷重変動に及ぼすひずみ速度の影響
}

\author{
上 剛司 ${ }^{* 1}$ ，山田 浩之 ${ }^{* 2}$ ，小笠原 永久 ${ }^{* 2}$
}

\section{Effect of strain rate on serrated load of indentation in Al-Mg alloy}

\author{
Tsuyoshi KAMI ${ }^{* 1}$, Hiroyuki YAMADA ${ }^{* 2}$ and Nagahisa OGASAWARA ${ }^{* 2}$ \\ ${ }^{* 1}$ Graduate School of Science and Engineering, National Defense Academy \\ 1-10-20 Hashirimizu, Yokosuka-shi, Kanagawa 239-8686 Japan \\ ${ }^{{ }_{2}}$ School of Systems Engineering, National Defense Academy \\ 1-10-20 Hashirimizu, Yokosuka-shi, Kanagawa 239-8686 Japan
}

Received: 9 June 2017; Revised: 12 September 2017; Accepted: 14 November 2017

\begin{abstract}
Indentation tests are used to determine the local mechanical properties of materials. Previously, the indentation strain rate was correlated with the strain rate in uniaxial tests based on the hardness, which was the obtained load divided by the cross-sectional area. However, the hardness can be influenced by pile-up of material after indentation. The purpose of this study was to relate the indentation strain rate with the uniaxial strain rate through serration behavior. The material used in this study was 5082 aluminum alloy, whose main alloying elements are aluminum and magnesium, and which is known to exhibit serration at certain temperatures and strain rates. Quasi-static uniaxial tensile tests were performed at strain rates from $10^{-4}$ to $10^{-1} \mathrm{~s}^{-1}$ at room temperature. Micro-indentation using a Berkovich indenter was performed at constant loading rates from 0.7 to $350 \mathrm{mN} / \mathrm{s}$. The loading curvature, which was defined as the load divided by the square of the displacement, was used instead of the hardness to avoid the pile-up effect. As a result, the serrated loading curvature in the indentation tests was obtained as the decreasing loading rate. The effective strain rate, which was defined as the derivative of the load with respect to time divided by two times the applied load, decreased with increasing displacement. The serrated loading curvature changed its behavior as the effective strain rate decreased. It behaved similarly to the serration observed in uniaxial tensile tests. It was found that the indentation strain rate is correlated with the strain rate in uniaxial tensile tests through the serration behavior.
\end{abstract}

Keywords : Indentation, Strain rate, Serration, Al-Mg alloy, Constant loading rate, Effective strain rate

\section{1. 緒言}

インデンテーション法は古くから硬さ試験として使用されてきた．硬さ $(H)$ は次式の通り圧子を材料に押込 むことによって得られる最大荷重 $\left(P_{\max }\right)$ を圧子の接触断面積 $(A)$ で除すことで求められる.

$$
H=\frac{P_{\max }}{A}
$$

インデンテーションは，ナノ・マイクロメートルオーダーの押込量で硬さの評価が可能であるため，現在まで 金属，複合材，ポリマー材等に幅広く応用されている(Fischer-Cripps, 2011).

圧子の種類は，図 1 に示寸模式図の示すように，主に円錐（Conical）, 四角錘 (Vickers), 三角錘 (Berkovich) が使用されている．幾何学形状は異なるが，投影面積（図中の影部）が同一であれば，圧子の形状に依らずイ ンデンテーションの結果は同じになることがわかっている(Fischer-Cripps, 2011).

No.17-00261 [DOI:10.1299/transjsme.17-00261], J-STAGE Advance Publication date : 22 November, 2017

${ }^{* 1}$ 正員, 防衛大学校 理工学研究科後期課程（广239-8686 神奈川県横須賀市走水 1-10-20）

*2 正員, 防衛大学校 システム工学群機械工学科

E-mail of corresponding author: kamimechnda@gmail.com 
(a)

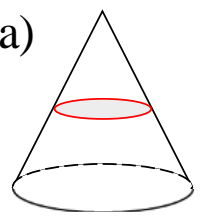

(b)

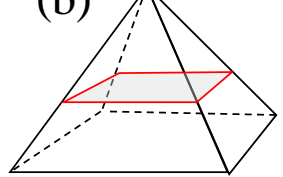

(c)

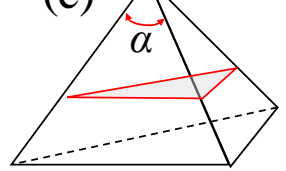

Fig. 1 Schematic image of indenters: (a) Conical (b) Vickers and (c) Berkovich ( $\alpha$ : indenter angle).

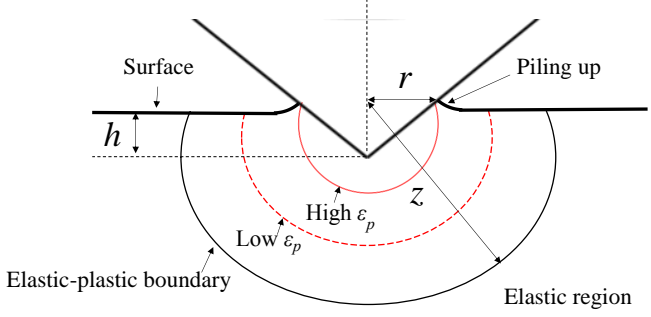

Fig. 2 Schematic diagram of strain distribution beneath the indenter. High plastic strain (High $\left.\varepsilon_{p}\right)$ was found at near the tip of the indenter, and value of the plastic strain gradually reduced at regions far from the tip (Low $\varepsilon_{p}$ ), until its value meets elastic-plastic boundary(Fischer-Cripps, 2011). $h$ is displacement, $r$ and $z$ are radius of contact and plastic strain distribution, respectively.

インデンテーションによる圧痕は小さく非破壊的に材料特性評価が可能である(Poon et al., 2008). しかし，圧 子直下の弾塑性ひずみ分布の範囲は，材料内部の広範囲に広がっている(Srikant et al., 2006). 圧子直下のひずみ 分布の概念図を図 2 に示寸，圧子直下のひずみ分布は，概茂形に分布しているが一様ではなく，圧子直下で 高いひずみ $\left(\right.$ High $\varepsilon_{p}$ ) を示し，材料内部に進むにつれ低ひずみ（Low $\varepsilon_{p}$ ）となり，弾塑性ひずみの境界

(Elastic-plastic boundary) へと至る. すなわち，インデンテーションのひずみ場は単軸試験とは異なり一般的に 不均一となる.

過去の研究では, 遅い圧子速度で行う準静的なインデンテーションにより材料特性が取得されてきた．しか し近年，圧子速度を変化させインデンテーションのひずみ速度の影響を考慮した研究が行われている．インデ ンテーションのひずみ速度 $\dot{\varepsilon}_{i}$ は次式で定義されている(Doerner and Nix, 1986), (Wei et al., 2007).

$$
\dot{\varepsilon}_{i}=b\left(\frac{1}{h} \frac{d h}{d t}\right)
$$

ここで, $b$ は材料定数， $h$ は変位， $t$ は時間であり, $\dot{\varepsilon}_{i}$ の単位は単軸試験のひずみ速度と同じ次元である.

例えば，本研究グループでは焼鈍した純銅と純アルミニウム材に対するインデンテーションで，圧子の負荷 速度を大きく寸ることにより荷重増加を確認している(山田他, 2012), (Yamada et al., 2013)。これは，単軸試験で 確認される材料強度のひずみ速度依存性がインデンテーションでも確認できることを意味している．また，微 細結晶粒 $\mathrm{Ni}$ に対し負荷速度を変化させたインデンテーションを行ってインデンテーションにおけるひずみ速度 感受性を求め，単軸試験のひずみ速度感受性と比較した報告例がある(Schwaiger et al., 2003). しかし，式（2) で定義されるインデンテーションのひずみ速度は変位 $h$ が増加すると減少するため, インデンテーションでひ ずみ速度を考慮する場合は，ひずみ速度の変化が最小もしくは影響を与えないほど小さな值になる深い押込量 にて評価が行われていた(Klassen et al., 2004)，(Bhakhri and Klassen, 2006). 現在まで, インデンテーションのひず み速度は定量化されておらず，インデンテーションのひずみ速度と単軸試験とひずみ速度の関連性は明らかに されていない.

一方， $\mathrm{Al}-\mathrm{Mg}$ 系合金（5000 系アルミニウム合金）を室温環境下で引張試験等を行うと，応力ーひずみ関係に 応力変動（セレーション）が現れることが知られている，セレーションは，溶質原子の雾囲気により転位が固 着や開放されることで生じる現象である（Portevin-Le Chatelier 効果）(Estrin et al., 1993). 試験温度が一定の条件 下でひずみ速度（転位移動速度）を変化させると, 転位が溶質原子に固着される時間が変化し, セレーション に変化が現れる，セレーションが起きると材料表面に模様が生じ(Thomas, 1966), 製品の表面状態が悪化するこ とから工学的にセレーションを抑制することが望ましい.このため, 現在まで発生条件等の研究がよく行われ てきた，単軸試験のセレーションはひずみ速度ごとに顕著な変化が表れるため，先行研究では，セレーション 
Table 1 Chemical Compositions of 5082 aluminum alloy（wt.\%）.

\begin{tabular}{c|c|c|c|c|c|c|c|c|c}
\hline \hline Alloy & $\mathrm{Si}$ & $\mathrm{Fe}$ & $\mathrm{Cu}$ & $\mathrm{Mn}$ & $\mathrm{Mg}$ & $\mathrm{Cr}$ & $\mathrm{Zn}$ & $\mathrm{Ti}$ & $\mathrm{Al}$ \\
\hline 5082 & 0.11 & 0.2 & 0.02 & 0.14 & 4.5 & 0.06 & 0.02 & 0.01 & Bal. \\
\hline
\end{tabular}

(a)

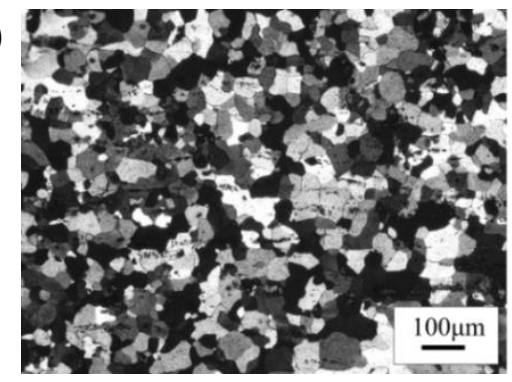

(b)

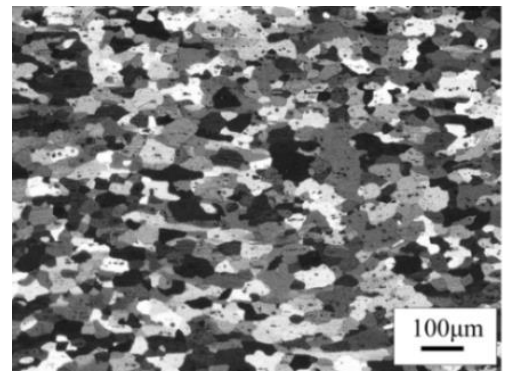

Fig. 3 Polarized microstructure of 5082 aluminum alloy: (a) Parallel to the rolling direction (b) Perpendicular to the rolling direction. Observed grains were close to equi-axed shape. Average grain size was approximately $32 \mu \mathrm{m}$.

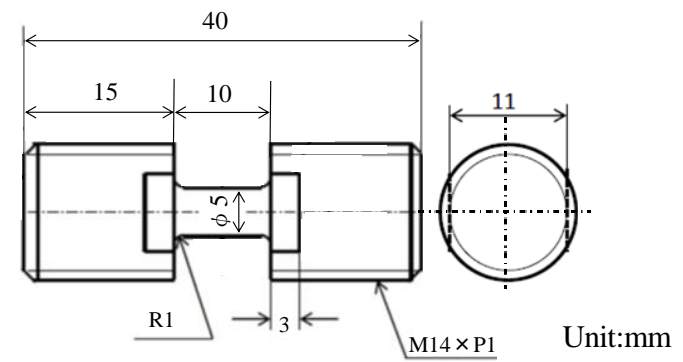

Fig. 4 Geometry of specimen used in tensile test.

挙動をひずみ速度，温度条件に関連させ分類分けが行われている(Pink and Grinberg, 1982). セレーションの発生 は，単軸引張や圧縮試験(Balasundaram et al., 2003)， 2 軸応力試験(Li and Lege, 1998), (Cieslar et al., 2003), ねじり (Wood and McCormick, 1987)等でも確認されている.

そこで本研究では, Al-Mg 系合金における単軸試験のひずみ速度に起因したセレーションの挙動変化からイ ンデンテーションのひずみ速度の指標を得ることができると考え，セレーションが現れる 5082 アルミニウム合 金に対して，負荷速度を変化させたインデンテーションを行った．本論文では，インデンテーションのひずみ 速度と単軸試験のひずみ速度の関連性を実験的に明らかにする。

\section{2. 実験方法}

\section{$2 \cdot 1$ 試 料}

試料は Al-Mg 系合金の一種である 5082 アルミニウム合金（以下 5082 合金と称する）を用いた。化学組成を 表 1 に示寸. 先行研究では同程度の Mg 量を含む材料でセレーションが観察されている(Pink and Grinberg, 1982). 試料は熱間圧延板材から旋盤加工により丸棒を作製し，圧延方向と丸棒の長さ方向を一致させた．偏光顕微鏡 により得られた圧延方向に平行および垂直な面の組織観察結果を図 3 に示寸. 結晶粒は概ね丸型から楕円形の 結晶粒であった。切片法で求めた平均結晶粒径は約 $32 \mu \mathrm{m}$ であった.

\section{$2 \cdot 2$ 準静的単軸引張試験}

上記の丸棒から旋盤加工により準静的単軸引張試験用の試験片を作製した．試験片形状を図 4 に示す. 平行 部の長さは $8 \mathrm{~mm}$ で長手方向が圧延方向になるように加工している. 焼鈍処理を $618 \mathrm{~K}$ で 2 時間行った. 準静的 単軸引張試験は，室温で Instron 社製万能試験機（5500R 型）を用いて行った．また，下記の式より算出した初 期ひず夕速度 $\dot{\varepsilon}$ は $1 \times 10^{-4}$ から $1 \times 10^{-1} \mathrm{~s}^{-1}$ である.

$$
\dot{\varepsilon}=\frac{V}{L}
$$

\section{ここで $V$ はクロスヘッド速度， $L$ は試験片の初期長さである.}



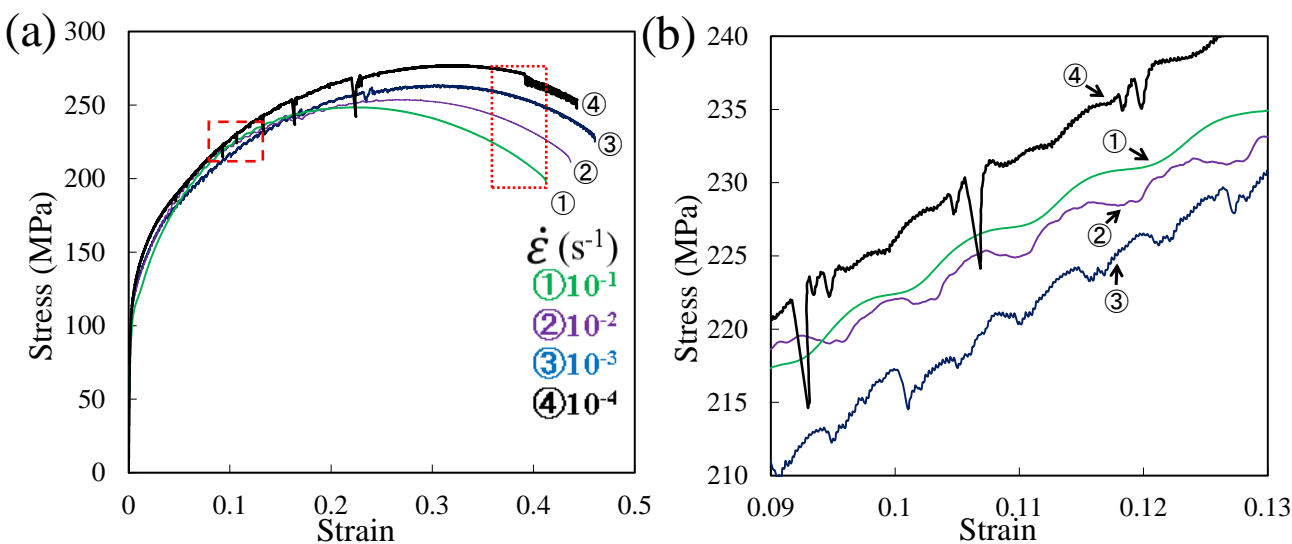

Fig. 5 (a) Nominal stress-nominal strain relationship of 5082 aluminum alloy at different strain rates. (b) Enlarged view of dashed rectangular box in (a). Dotted rectangular area was used in Fig. 6 (c). Serrated stress-strain curves were obtained at all of tested strain rates.

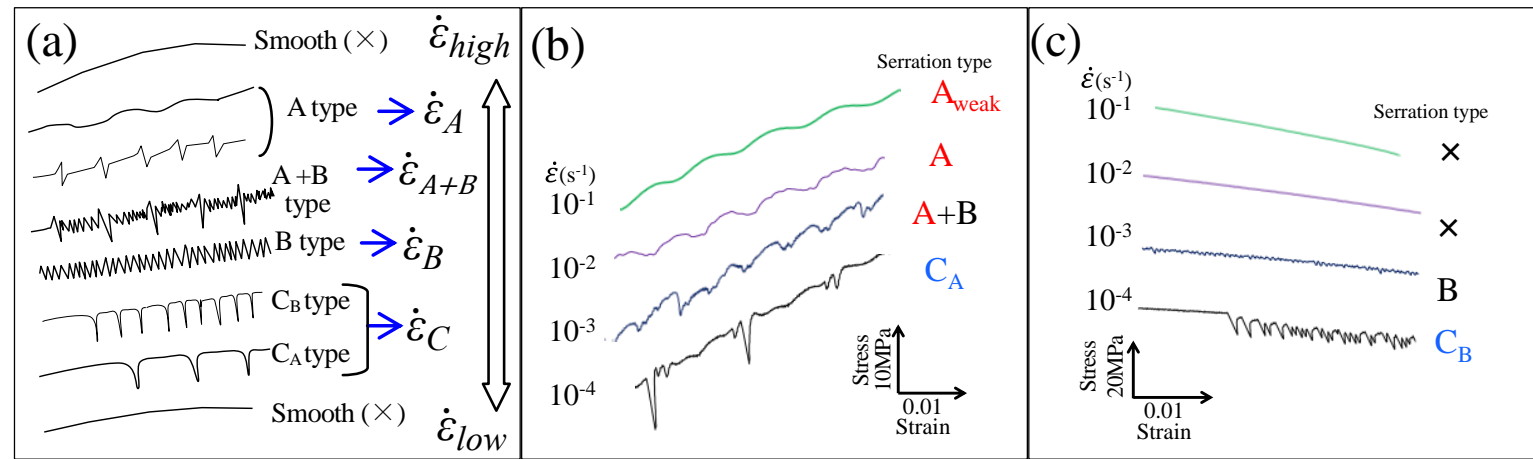

Fig. 6 (a) Schematic image of reported serration and its type. (b), (c) Observed serration behaviors at each strain rates. (b) during uniform elongation (c) after necking. Serration behavior changed at different strain rates. Some of serration behaviors disappeared due to effect of necking.

\section{$2 \cdot 3$ マイクロインデンテーション}

前項と同じ試料から円柱試験片（ $\phi 14 \mathrm{~mm} \times 14 \mathrm{~mm} ）$ を旋盤で切出し，エメリー研磨（\#800，1200，2400）, バ フ研磨（アルミナ粒径 $1 \mu \mathrm{m}$ および $0.3 \mu \mathrm{m}$ ）により鏡面に仕上げた．この状態のままで，マイクロインデンテー ションを行うと研磨による加工硬化層の影響を受けるため, $618 \mathrm{~K} て ゙ 2$ 時間の焼鈍処理を行った.

マイクロインデンテーションは，島津製作所製ダイナミック超微小硬度計（DUH-211S）を用いた．圧子は図 2 (c) に示すダイヤモンド製の Berkovich 圧子（ $\left.\alpha=115^{\circ}\right)$ を使用した．本研究では，荷重速度制御で負荷速度 一定の $0.7 \sim 350 \mathrm{mN} / \mathrm{s}$ の範囲で行い，最大荷重 $1900 \mathrm{mN}$ で 30s 保持した後，同速度で除荷した.

\section{$3 \cdot 1$ 準静的単軸引張試験}

\section{3. 実験結果}

引張試験より得た 5082 合金の公称応力一公称ひずみ線図を図 5 （a）に示す．図中の破線で囲んだ領域の拡大 図を図 5 (b) に示した。引張強さや破断強度はひずみ速度の増加に伴い減少し，材料強度の負のひずみ速度依 存性の傾向を示した。 これは, 低ひずみ速度の試験では転位密度の増加に伴い $\mathrm{Mg}$ 原子が転位を強く固着し, 高 ひずみ速度の試験では低ひずみ速度の試験に比べ転位の固着作用が弱くなるためである(Picu et al., 2005). また, 全てのひずみ速度域でセレーションが生じた. 先行研究 (例えば, (Pink and Grinberg, 1982), (池野他, 1988)) で, ひずみ速度の変化によりセレーション挙動が変化することがわかっており，代表的な例を図 6 (a) にまとめた. セレーションはある一定のひずみ速度域で発生し, 比較的高ひずみ速度 $\left(\dot{\varepsilon}_{A}\right)$ で発生する上昇および降下を繰り 返す応力変動または波状の応力変動を $\mathrm{A}$ タイプ, 中程度のひずみ速度 $\left(\dot{\varepsilon}_{B}, \dot{\varepsilon}_{A+B}\right)$ で発生する鋸歯状の応力変 動を B タイプ, A と B の混合の A+B タイプ, 低ひずみ速度 $\left(\dot{\varepsilon}_{C}\right)$ で見られる応力降下が主な変動の $\mathrm{C}$ タイプ (変 動の頻度により $\mathrm{C}_{A}, \mathrm{C}_{B}$ タイプ）に分類されている.また，ひずみ速度が， $\dot{\varepsilon}>\dot{\varepsilon}_{A}$ もしくは $\dot{\varepsilon}<\dot{\varepsilon}_{C}$ の場合は， セレーションは発生せず，滑らかな応力ーひずみ線図となる（凡例 $\times)$.

図 5 （a）の破線および点線部から抽出したセレーションの代表例とその分類を図 6 (b), (c) に示す. 引張強さ 
Kami, Yamada and Ogasawara, Transactions of the JSME (in Japanese), Vol.83, No.856 (2017)
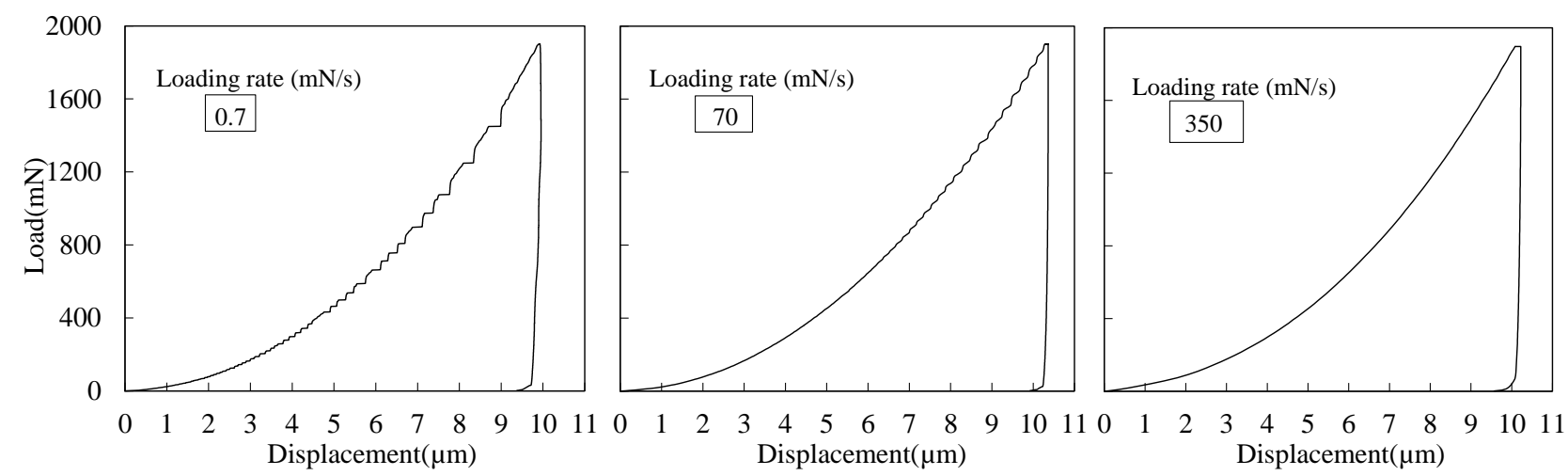

Fig. 7 Load-displacement relationship at different constant loading rates. As decreasing the loading rate, serrated indentation loads were observed.

(a)

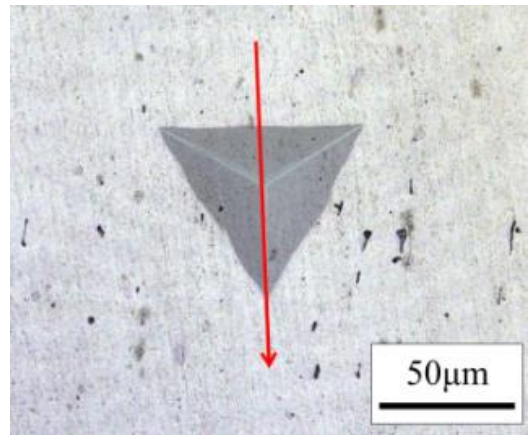

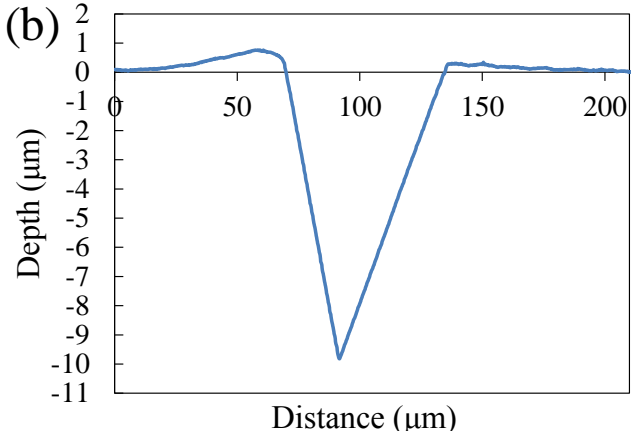

Distance $(\mu \mathrm{m})$

Fig. 8 (a) Optical micrograph of impression with surface profile direction. (b) Surface profile of the impression. Slight piling up was observed.

までの均一変形間は, 初期ひずみ速度 $1 \times 10^{-4}$ から $1 \times 10^{-1} \mathrm{~s}^{-1}$ までセレーションを確認した．ひずみ速度とセレ ーションの関係は，Al-5 wt.\%Mg 合金の先行研究と同様であった(Pink and Grinberg, 1982). また，ひずみ速度が $1 \times 10^{-1} \mathrm{~s}^{-1}$ で最も変動の小さいセレーションとなった（凡例 $\mathrm{A}_{\text {weak }}$ )。 ネッキング以降は, 初期ひずみ速度 $1 \times 10^{-4}$ および $1 \times 10^{-3} \mathrm{~s}^{-1}$ でセレーションを確認したが，ひずみ速度 $1 \times 10^{-2}$ および $1 \times 10^{-1} \mathrm{~s}^{-1}$ ではセレーションが確認 できなくなった，以上のようにセレーションは均一変形間，ネッキング以降で変化が生じた．ネッキングによ るセレーションの変化は, ミクロポアの連結やボイド生成等の影響が考えられるが, 単純にひずみ速度の観点 から考えると，ネッキングにより変形領域が局所的になったことで，式（3）の分母が小さくなり，ひずみ速度 が均一変形時に比べて速くなったことも要因と言える.

Liu らは材料特性值を様々変化させた有限要素法解析により, インデンテーションに直接影響のあるひずみは, 本実験で使用した圧子角度の場合, 単軸試験のひずみ約 0.2 までとしている(Liu et al., 2008). そこで本研究では, Liu らの研究成果を参考に, 均一変形間で確認できたセレーションの分類を使用し考察を進める.

\section{$3 \cdot 2$ インデンテーション}

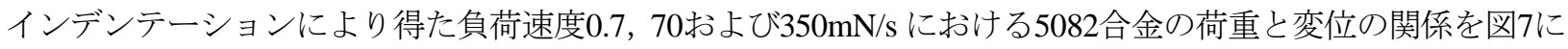
示し，付録 1 に荷重変動が確認できた負荷速度 $0.7,70 \mathrm{mN} / \mathrm{s}$ の3回の試験結果を示した. 荷重変動の大きさは，各 負荷速度ごとほぼ差異がないことを確認している． $0.7 \mathrm{mN} / \mathrm{s}$ では階段状の荷重変動が確認できるのに対し， $70 \mathrm{mN} / \mathrm{s}$ では変動の度合いが小さくなり，350mN/s では変動が確認できなかった．以上のことからインデンテー ションでは負荷速度が遅くなるにつれて, 負荷過程における荷重が大きく変動することがわかった.

除荷後の圧痕周辺の起伏をレーザー顕微鏡（キーエンス社製 VK-X260）にて観察を行った．図8（a）に観察 した $0.7 \mathrm{mN} / \mathrm{s}$ における圧痕の一例を示す. 図8（a）の図中に矢印で図8（b）のプロファイル方向を示した. 図8 (b) からわかるように圧痕周辺ではアルミニウム合金で通常観察される材料の盛上がり (中村, 2007) が観察で きた．全ての負荷速度で除荷後の圧痕面や圧痕周りの盛上がりの観察を行ったが，負荷速度の違いによる㾗 の変化は認められず, 荷重変動の影響は確認できなかった。 これは, インデンテーションのひずみ場は主に材 


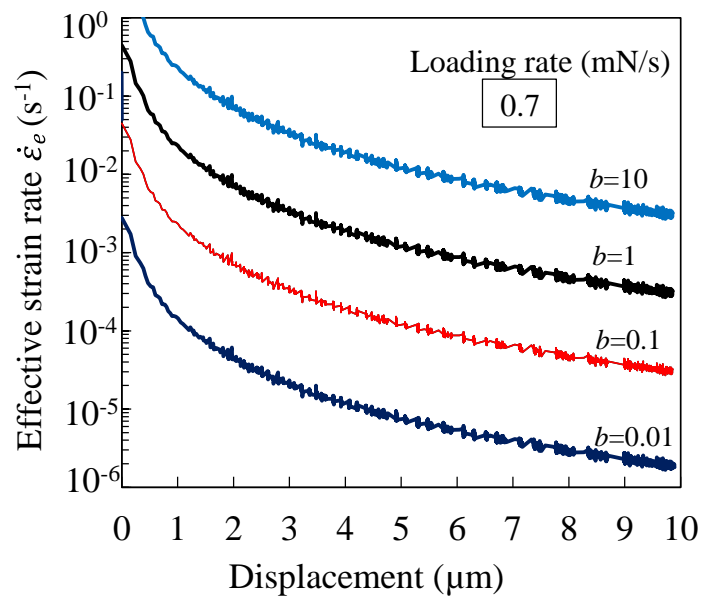

Fig. 9 Effective strain rate-displacement relationship of $0.7 \mathrm{mN} / \mathrm{s}$ with different values of material constant $b$. Effective strain rate decreased with displacement.

料内部に分布しているため(Yamada et al., 2015)と考えられる.

図 3 と図 8 の結果から圧子直下のひずみ分布に影響を受ける結晶粒について考える.インデンテーションは 微小領域の変形であるが, 図 2 に示す圧子直下のひずみ分布は広範囲に分布している. 先行研究では, 図 2 の 接触半径 $(r)$ と弾塑性ひずみの境界の半径 $(z)$ の比 $z / r$ に関する報告例がある. 同じ $r$ の場合, $z / r$ 比が大き くなるほど，圧子直下のひずみ分布は大きくなる. Srikant らは自然時効後の 7075 アルミニウム合金に対しイン デンテーションを行い, 圧子直下の $z / r$ は約 1.3〜2.2 と概算している(Srikant et al., 2006). また, Tirupataiah らは 7039 アルミニウム合金の溶体化処理直後，ピーク時効，過時効での $z / r$ を求め，最も大きな $z / r$ 示したのは溶 体化処理後の場合であり, その時の $z / r$ は約 2.5 と報告している(Tirupataiah and Sundararajan, 1991). 加工硬化す る材料の $z / r$ は加工硬化しない材料より大きい傾向にある(Tirupataiah and Sundararajan, 1991). このため, 今回の 試料である焼鈍した 5082 合金は，時効硬化した 7075，7039アルミニウム合金より加工硬化することから $z / r$ は 同等程度か $z / r=2.5$ より大きいことが予想される.

図 8 の三角錐圧子による圧痕から材料と圧子の接触長さを求めると約 $66 \mu \mathrm{m}$ であった. ここで, 簡易的に圧子 を半径 $33 \mu \mathrm{m}$ の接触半径をもつ円錐圧子と置き換えて図 2 に示すひずみ分布の概算を行う. 前述の $z / r$ を 2.5 と

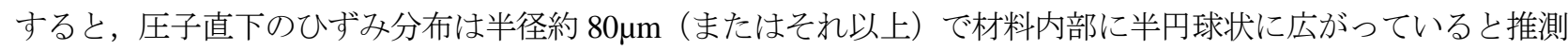
できる．仮に，今回の試料の結晶粒を粒径約 $32 \mu \mathrm{m}$ （平均結晶粒形）の完全な球形かつ圧子直下のひずみ分布は 半円球状に分布すると仮定すると，インデンテーションにより発生した圧子直下のひずみ分布は材料内部で約 70 個の結晶粒に影響を与えていると考えられる. よって, インデンテーションでは, 圧子直下のひずみ分布が 多数の結晶粒に影響を及ぼしているため, 単軸試験等の結果と密接に関連寸ると考えられる。そこで両試験結 果のひずみ速度の影響を考慮し考察を行う。

\section{4. 考 察}

\section{$4 \cdot 1$ インデンテーションの先行研究とひずみ速度}

著者らの研究グループでは, 有限要素法解析を用いて材料内部のインデンテーションのひずみ速度 $\dot{\varepsilon}_{i}$ は圧子 直下に不均一なひずみ速度分布を有することを明らかにし, そのひずみ速度分布を平均化して単一的に扱う手 法を提案した (Yamada et al., 2015). しかし，実験では，ひずみ速度分布の取得が困難であるため，式（2）のイ ンデンテーションのひずみ速度を有効ひずみ速度 $\dot{\varepsilon}_{e}$ と定義し, ひずみ速度分布ではなく簡易的に単一の值とし て取り扱い，単軸試験のひずみ速度と関連性が調べられている(Lucas and Oliver, 1999).

$$
\dot{\varepsilon}_{e}=b\left(\frac{\dot{h}}{h}\right) \approx b\left(\frac{\dot{P}}{2 P}\right) \approx \dot{\varepsilon}
$$

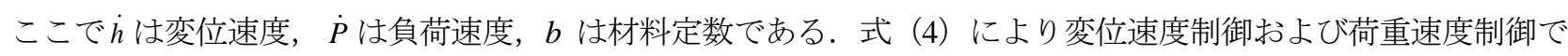
の評価が可能である，本論文では，実験結果をひずみ速度分布等から影響を受けた出力值として取り扱い議論 
を行う． $0.7 \mathrm{mN} / \mathrm{s}$ で得たインデンテーションの有効ひずみ速度と変位の関係を図 9 に示す. 式 (4) の材料定数 は Poisl ら(Poisl et al., 1994)の值（ $b=0.071 \sim 0.286 ）$ を参考に $b$ の值を $0.01 〜 10$ まで任意に変化させた. $b$ の值に 関わらず，変位が増加すると有効ひずみ速度が減少していることがわかる.

古くからインデンテーションと単軸試験の関連性については盛んに調べられている. Tabor は, Vickers 圧子を 使用し, 準静的単軸試験での材料の流動応力はインデンテーションにより得た硬さと相関性があることを提案 した (Tabor, 1956). 特に, インデンテーションの硬さと関連する単軸試験の流動応力は代表応力 $\left(\sigma_{r}\right)$ と定義さ れ. 以下の関係式が提案されている.

$$
H \approx A \sigma_{r}
$$

ここで $A$ はおよそ 1 3 の材料定数, $\sigma_{r}$ は単軸試験のひずみ 0.08 における流動応力である. このひずみ量は代表 ひずみと呼ばれている．式（5）は経験的に決められたものであるが，低炭素鋼，アルミニウム，銅等の様々な 材料で成り立つことが確認されている(Tabor, 1956), (中村, 2007)。しかしながら，硬さは，断面積の測定精度に 左右され, 図 2 の盛上がり等が発生する場合は正確な断面積の決定は難しい(Taljat and Pharr, 2004).

式（5）の考えに基づき，インデンテーションの有効ひずみ速度と単軸試験のひずみ速度の関係性が調べられ ている(Alkorta et al., 2008). 単軸試験のひずみ速度に相当するインデンテーションの有効ひずみ速度の概算は, 式 (6)，(7) で定義されるひずみ速度感受性 $m$ を比較することで検討されてきた. (Moody et al., 1998), (Pan et al., 2008), (Maier et al., 2011).

$$
\begin{gathered}
m_{\text {uniaxial }}=\frac{\partial \ln \sigma}{\partial \ln \dot{\varepsilon}} \\
m_{\text {indentation }}=\frac{\partial \ln H}{\partial \ln \dot{\varepsilon}_{e}}
\end{gathered}
$$

同様にインデンテーションのクリープ試験でも単軸クリープ試験と比較するために硬さと有効ひずみ速度が 使用されている(Poisl et al., 1994). しかし，式（7）を使用した比較は硬さを使用するため，盛上がり等の影響を 受けるため問題がある.

一方，インデンテーションにおいて荷重 $(P)$ と変位 $(h)$ の関係は次式で表される(Fischer-Cripps, 2011).

$$
P=C h^{2}
$$

ここで $C$ は負荷曲率と呼ばれており, 単軸試験の応力と同じ次元である. 負荷曲率は, 材料の弾塑性特性, 圧 子角度や温度, ひずみ速度等の試験条件に依存するため, 次式のような関数 $f$ として表すことができる.

$$
C=f\left[E^{*}, \sigma_{r}, v, v_{i}, \alpha, T, \dot{\varepsilon}\right]
$$

ここで， $E^{*}$ は圧子と材料の複合ヤング率，vは材料のポアソン比， $v_{i}$ は圧子のポアソン比， $\alpha$ は圧子角度， $T$ は 試験温度である.インデンテーションにおいてポアソン比の影響は小さいことがわかっている(Mesarovic and Fleck, 1999), (Chen and Vlassak, 2001). 本実験では， $E^{*} ， \alpha$ おび $T$ は一定であるため， $\sigma_{r}$ と $\dot{\varepsilon}$ が負荷曲率と 密接な関係がある。また, 負荷曲率の取得には, 断面積を測定する必要がないため, 盛上がり等の影響を受け ない.

先行研究では, ひずみ速度の影響を考慮しない準静的なインデンテーションの数值解析において, 負荷曲率 を利用した材料特性評価が行われている. 例えば, 材料の負荷曲率と代表ひずみ值を適切に選択することで, 単軸試験の応力ーひずみ曲線をインデンテーションの結果より求めることが可能である(Dao et al., 2001), (Ogasawara et al., 2005).

以上を踏まえ, 本研究では負荷曲率と有効ひずみ速度の関係からインデンテーションの結果を考察する. 
(a) $0.7 \mathrm{mN} / \mathrm{s}$

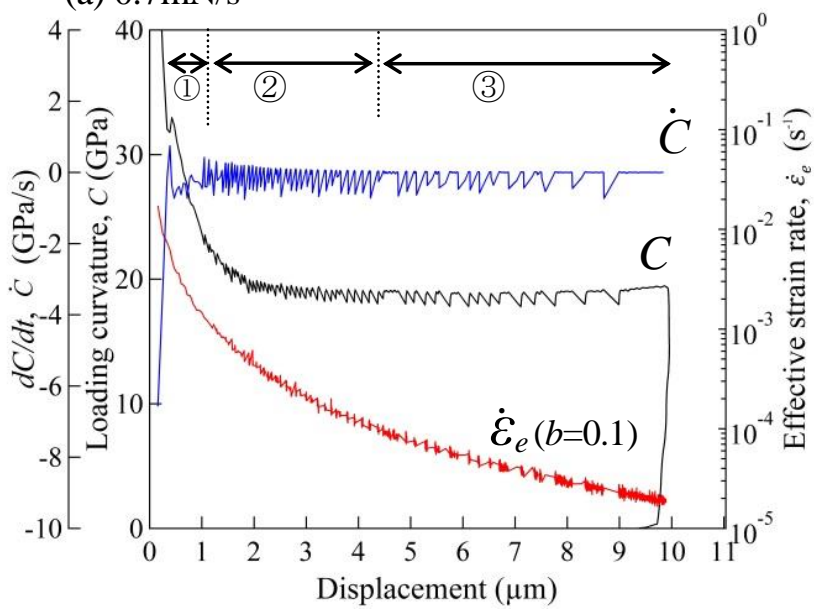

(c) $70 \mathrm{mN} / \mathrm{s}$

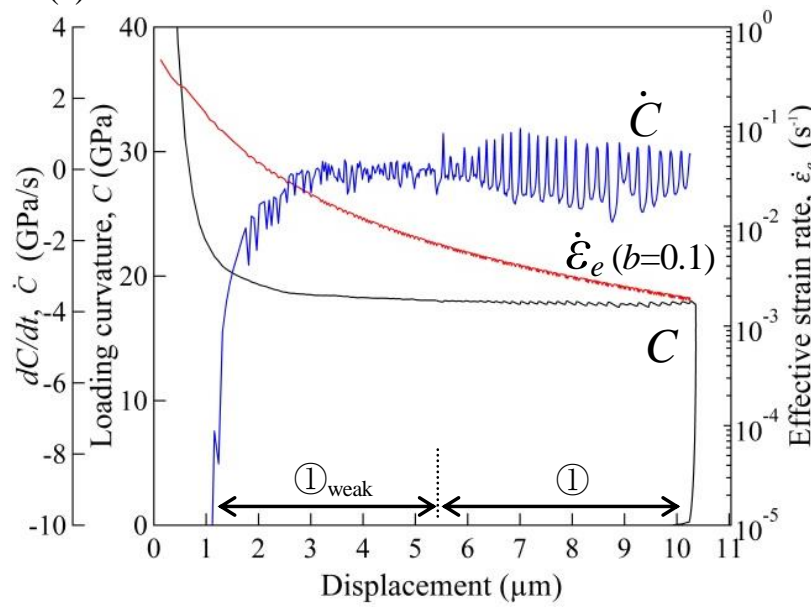

(b) Enlarged view of $0.7 \mathrm{mN} / \mathrm{s}$ result

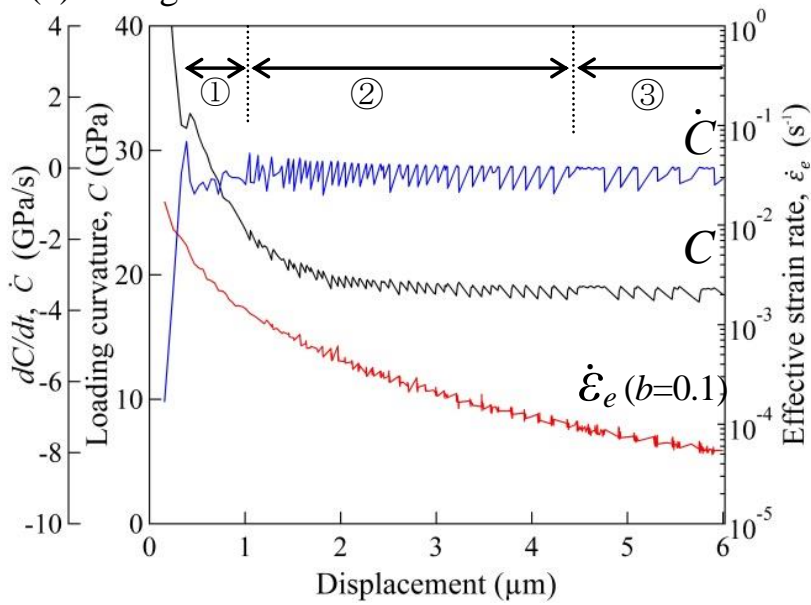

(d) Enlarged view of $70 \mathrm{mN} / \mathrm{s}$ result

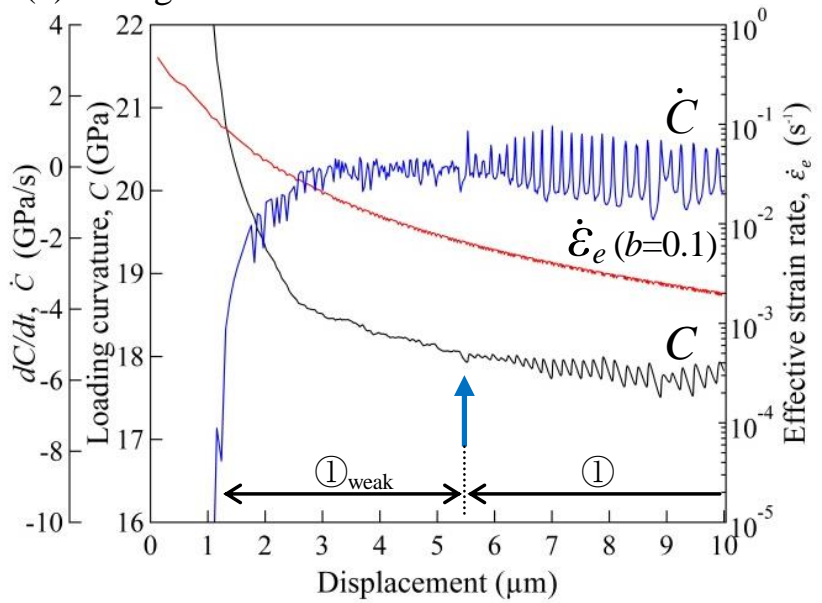

Fig. 10 (a) Relationship between loading curvature and displacement with derivative of loading curvature and effective strain rate at $0.7 \mathrm{mN} / \mathrm{s}$ (b) Enlarged view of $0.7 \mathrm{mN} / \mathrm{s}$ results. (c) Relationship between loading curvature and displacement with derivative of loading curvature and effective strain rate at $70 \mathrm{mN} / \mathrm{s}$ (d) Enlarged view of $70 \mathrm{mN} / \mathrm{s}$ results. Behavior of serrated loading curvature was changed as decreasing displacement.

\section{$4 \cdot 2$ インデンテーションの有効ひずみ速度と負荷曲率変動の関係}

負荷速度 $0.7 \mathrm{mN} / \mathrm{s}, 70 \mathrm{mN} / \mathrm{s}$ で得たインデンテーションの負荷曲率と変位の関係を図 10 に示す. 図中に負荷過 程における負荷曲率の時間微分 $(\dot{C}=d C / d t)$ と $b$ を 0.1 とした場合の有効ひずみ速度も併せて示した．試験時間 は $0.7 \mathrm{mN} / \mathrm{s}$ が約 2700 秒, $70 \mathrm{mN} / \mathrm{s}$ が約 30 秒であったため，負荷曲率の時間微分の值には大きな差が見られた. 負荷速度 $0.7 \mathrm{mN} / \mathrm{s}, 70 \mathrm{mN} / \mathrm{s}$ ともに変位が増加するにつれて, 負荷曲率の変動の様子が変化することがわかった. 例えば図 10 (d) で負荷曲率が変位約 $5.4 \mu \mathrm{m}$ 急に大きな変動を示した（図中矢印）。これは式 (4) で定義される 通り荷重速度制御において荷重の増加に伴い有効ひずみ速度が減少し,転位が $\mathrm{Mg}$ 原子に固着されやすいひずみ 速度域になったためと考えられる. 式（4）の $b$ が 0.1 の場合，負荷速度 $0.7 \mathrm{mN} / \mathrm{s}$ の有効ひずみ速度は，負荷過 程間におよそ $10^{-2}$ から $10^{-5} \mathrm{~s}^{-1}$ まで幅広く変化し，70 $\mathrm{mN} / \mathrm{s}$ の有効ひずみ速度は，およそ $10^{-1}$ から $10^{-3} \mathrm{~s}^{-1}$ まで変化 していることがわかった.

インデンテーションの負荷曲率変動に変化が見られたため, 以下の 4 つの領域に分類する.

I 。負荷曲率の変動が微小であり，主に負荷曲率の時間微分により変動が確認できる領域（領域 $\left(1_{\text {weak }}\right)$

II. 負荷曲率の変動が開始し上昇と降下を繰り返寸領域（領域(1)

III. 負荷曲率が大きく鋸歯状に変動する領域（領域(2)

IV．負荷曲率が降下および上昇を不定期の間隔で繰り返す領域（領域(3)

上記領域を図10の図中に示した．0.7，70mN/sの結果から有効ひずみ速度の減少に伴って，領域が(1 weak $_{\text {wら (3) }}$ 変化していることがわかる. 
(a)

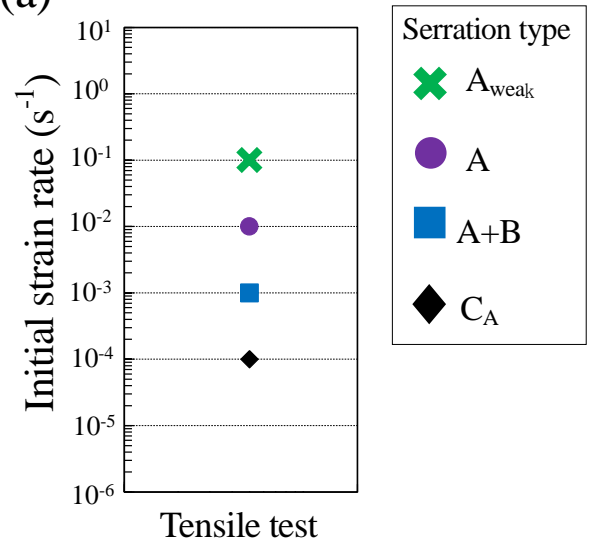

(b)

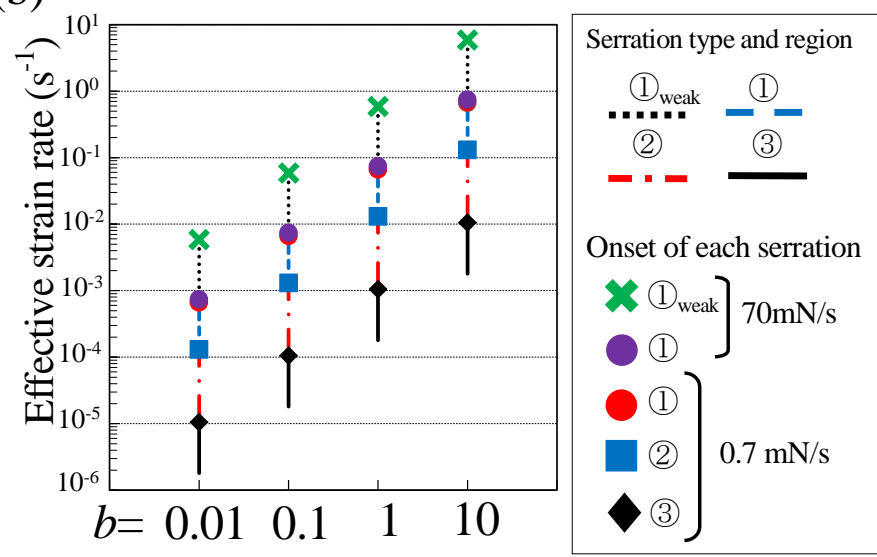

Fig. 11 (a) Summary of serration type with initial strain rate in tensile test. (b) Relationship of effective strain rate and types of serrated loading curvature obtained from loading rate $0.7,70 \mathrm{mN} / \mathrm{s}$. Effective strain rate can be closely related to strain rate of uniaxial test, if material constant $b$ is 0.1 .
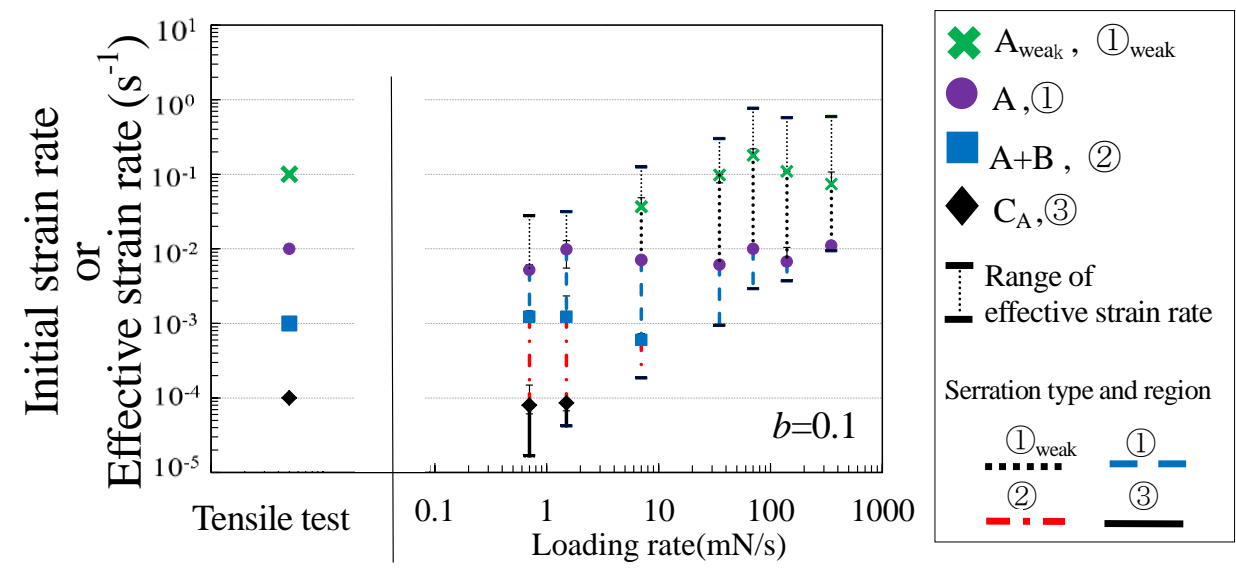

Fig. 12 Summary of serration type with initial strain rate and effective strain rate obtained from tensile test and indentation. Serrated loading curvature and effective strain rate relationship was closely related with serration and initial strain rate of tensile test.

\section{$4 \cdot 3$ 引張試験のセレーションとインデンテーションの負荷曲率変動の比較}

引張試験で観察した均一変形間のセレーションとインデンテーションの負荷曲率変動の比較を行う. 図 11 (a) に引張試験の各初期ひずみ速度に対応するセレーションの分類を示し，図 11 (b) に各 $b$ の值（0.01～10）によ り求めた有効ひずみ速度と負荷曲率変動の関係を示した. $b$ が 0.1 の時が最も引張試験の初期ひずみ速度とセレ ーションの関係に対応することがわかった．試料として用いた 5082 合金の $b$ の值は，未知であり比較できる先 行研究がないため, $b$ 值を取り扱っている他の研究を参考に検討を行う. Poisl らは，アモルファスのセレニウ ムに対するインデンテーションを行い, 単軸のクリープ速度に対応するインデンテーションのクリープ速度 (有 効ひずみ速度) を求め, $b$ 值を 0.09(Poisl et al., 1994) とした. また, Alkorta らは材料のクリープ速度感受性指数 を変化させ, 有限要素法解析によりインデンテーションクリープ試験を行い $b$ 值を 0.128 と提案している(Alkorta et al., 2008). 他の論文では，簡易的に $b \approx 0.1$ としてアモルファスの金属ガラス(Wei et al., 2007)や結晶構造を持 つ微細結晶 $\operatorname{Mg}$ (Somekawa and Mukai, 2010)に対するインデンテーションを行い, インデンテーションのひずみ速 度と単軸試験とのひずみ速度との関連性が調査されている．本研究では $b$ 值を任意に変化させた結果 $(b=0.01$ ～10), 最も有効ひずみ速度と単軸試験のひずみ速度が関連する $b$ は 0.1 であり, 導出方法, 材料は異なるが他 の文献と近い值を示した.

図 10 と同様の手順で負荷速度を 1.5 から $350 \mathrm{mN} / \mathrm{s}$ の範囲で変化させ, 負荷速度の変化（有効ひずみ速度の变 化）に伴う負荷曲率変動を観察した（付録 2 参照）．図 12 に $b=0.1$ の時の有効ひずみ速度と負荷曲率変動の領 域と引張試験のセレーションの分類の比較を示す．有効ひずみ速度は試験中に変化するので，変化した範囲を 図 12 の図中に示した. インデンテーションで得た負荷曲率変動の領域は, 概ね引張試験のセレーションタイプ とひずみ速度の関係と一致している．このことから，5082 合金のセレーション挙動をインデンテーションの有 
効ひずみ速度と負荷曲率変動から評価が可能であることが明らかになった．また，セレーションを利用するこ とでインデンテーションの有効ひずみ速度と $b$ の值が概算でき, 単軸試験のひずみ速度に対応するインデンテ ーションの有効ひずみ速度の指標を得ることができた.

現在まで $b$ の值の物理的な意味は明らかにされていない，圧子直下のひずみ速度分布は，鋭い圧子に起因し て材料内部に高ひずみ速度，低ひずみ速度領域が存在することがわかっており(Yamada et al., 2015)，今後は，ひ ずみ速度場を考慮して $b$ の值の考察を行う必要がある. しかし, 本実験で使用した圧子と 5082 合金の場合，有 効ひずみ速度が単軸試験のひずみ速度の約 0.1 倍という本研究で得た結果は, インデンテーションのひずみ速度 を考察する上で有意な情報である.

\section{5. 結言}

本研究では，セレーションを利用してインデンテーションのひずみ速度の指標を得ることを目的に，5082 ア ルミニウム合金に対して準静的単軸引張試験およびインデンテーションを行った. その結果，インデンテーシ ヨンの荷重変動（負荷曲率変動）は，有効ひずみ速度に起因して発生することがわかった。また，負荷曲率変 動は, 準静的単軸引張試験のセレーション挙動と同様にひずみ速度の変化に応じて分類ができた. 負荷曲率変 動の挙動を利用し, 準静的引張試験とインデンテーションの結果を比較すると, 有効ひずみ速度の材料定数 $b$ の概算が可能になり，インデンテーションのひずみ速度の指標を得ることができた.

本研究により, セレーション挙動を利用することでインデンテーションのひずみ速度と単軸試験のひずみ速 度との関連性を示すことができた。

\section{謝 辞}

本研究の一部は，JSPS 科研費若手研究（A）（課題番号 JP25709004）の助成を受けて行った．また，株式会社 UACJ 岡田 峰光氏には，5082 合金のご提供と偏光顕微鏡観察にご協力頂きました．ここに記して謝意を表し ます。

\section{文献}

Alkorta, J., Martínez-Esnaola, J. M. and Sevillano, J. G., On the elastic effects in power-law indentation creep with sharp conical indenters, Journal of Materials Research, Vol.23, No.1 (2008), pp.182-188, doi:10.1557/JMR.2008.0011.

Balasundaram, A., Gokhale, A. M., Graham, S. and Horstemeyer, M. F., Three-dimensional particle cracking damage development in an Al-Mg-base wrought alloy, Materials Science and Engineering A, Vol.355, No.1-2 (2003), pp.368-383, doi:10.1016/S0921-5093(03)00103-5.

Bhakhri, V. and Klassen, R. J., Investigation of high-temperature plastic deformation using instrumented microindentation tests. part I the deformation of three aluminum alloys at $473 \mathrm{~K}$ to $833 \mathrm{~K}$, Journal of Materials Science, Vol.41 (2006), pp.2259-2270, doi:10.1007/s10853-006-7174-7.

Chen, X. and Vlassak, J. J., Numerical study on the measurement of thin film mechanical properties by means of nanoindentation, Journal of Materials Research, Vol.16, No.10 (2001), pp.2974-2982.

Cieslar, M., Fressengeas, C., Karimi, A. and Martin, J. L., Portevin-le chatelier effect in biaxially strained Al-Fe-Si foils, Scripta Materialia, Vol.48, No.8 (2003), pp.1105-1110, doi:10.1016/S1359-6462(02)00617-6.

Dao, M., Chollacoop, N., Van Vliet K. J., Venkatesh, T.A. and Suresh, S., Computational modeling of the forward and reverse problems in instrumented sharp indentation, Acta Materialia, Vol.49, No.19 (2001), pp.3899-3918, doi:10.1016/S1359-6454(01)00295-6.

Doerner, M. F. and Nix, W.D., A method for interpreting the data from depth-sensing indentation instruments, Journal of Materials Research, Vol.1, No.4 (1986), pp.601-609.

Estrin, Y., Kubin, L. P. and Aifantis, E. C., Introductory remarks to the viewpoint set on propagative plastic instabilities, Scripta Metallurgica et Materiala, Vol.29, No.9 (1993), pp.1147-1150, doi:10.1016/0956-716X(93)90100-7.

Fischer-Cripps, Anthony C., Introduction to contact mechanics, Springer (2007).

Fischer-Cripps, Anthony C., Nanoindentation, Springer (2011), doi:10.1007/978-1-4419-9872-9.

池野進, 浦野寛幸, 上谷保裕, 多々静夫, Al-10\% Mg合金のセレーションに及ぼす時効処理の影響, 軽金属, Vol.38, No.8 (1988), pp.473-478.

Klassen, R. J., Diak, B. J. and Saimoto, S., Origin of the depth dependence of the apparent activation volume in polycrystalline $99.999 \% \mathrm{Cu}$ determined by displacement rate change micro-indentation, Materials Science and Engineering A, Vol.387-389 (2004), pp.297-301, doi:10.1016/j.msea.2004.02.079. 
Li, M. and Lege, D.J., Serrated flow and surface markings in aluminum alloys, Journal of Engineering Materials and Technology, Vol.120, No.1 (1998), pp.48, doi:10.1115/1.2806837.

Liu, L., Ogasawara, N., Chiba, N. and Chen, X., Can indentation technique measure unique elastoplastic properties ?, Journal of Materials Research, Vol.24, No.3 (2008), pp.784-800, doi:10.1557/JMR.2009.0100.

Lucas, B. N. and Oliver, W. C., Indentation power-law creep of high-purity indium, Metallurgical and Materials Transactions A, Vol.30A (1999), pp.601-610.

Maier, V., Durst, K., Mueller, J., Backes, B., Höppel, H. and Göken, M, Nanoindentation strain-rate jump tests for determining the local strain-rate sensitivity in nanocrystalline $\mathrm{Ni}$ and ultrafine-grained $\mathrm{Al}$, Journal of Materials Research, Vol.26, No.11 (2011), pp.1421-1430, doi:10.1557/jmr.2011.156.

Mesarovic, S. D. and Fleck, N. A., Spherical indentation of elastic-plastic solids, Proceedings of the Royal Society London A, Vol.455 (1999), pp.2707-2728, doi:10.1098/rspa.1999.0423.

Moody, N.R., A, Strojny., Medlin, D., Gutherie, S. and Gerberich, W.W., Test rate effects on the mechanical behavior of thin aluminum films, Materials Research Society Symposium Proceedings, 522:281-286 (1998).

中村雅勇, 硬さ試験の理論とその利用法, 工業調査会 (2007).

Ogasawara, N., Chiba, N. and Chen, X., Representative strain of indentation analysis, Journal of Materials Research, Vol.20, No.08 (2005), pp.2225-2234, doi:10.1557/JMR.2005.0280.

Pan, D., Inoue, A., Sakurai, T. and Chen, M. W., Experimental characterization of shear transformation zones for plastic flow of bulk metallic glasses., Proceedings of the National Academy of Sciences of the United States of America, Vol.105, No.39 (2008), pp.14769-14772, doi:10.1073/pnas.0806051105.

Picu, R.C., Vincze, G., Ozturk, F., Gracio, J.J., Barlat, F. and Maniatty, A.M., Strain rate sensitivity of the commercial aluminum alloy AA5182-O, Materials Science and Engineering A, Vol.390 (2005), pp.334-343, doi:10.1016/j.msea.2004.08.029.

Pink, E. and Grinberg, A., Stress drops in serrated flow curves of Al5Mg, Acta Metallurgica, Vol.30, No.12 (1982), pp.2153-2160, doi:10.1016/0001-6160(82)90136-5.

Poisl, W.H., Oliver, W.C. and Fabes, B.D., The relationship between indentation and uniaxial creep in amorphous selenium, Journal of Materials Research, Vol.10, No.08 (1994), pp.2024-2032, doi:10.1557/JMR.1995.2024.

Poon, B., Rittel, D. and Ravichandran, G, An analysis of nanoindentation in linearly elastic solids, International Journal of Solids and Structures, Vol.45, No.24 (2008), pp.6018-6033, doi:10.1016/j.ijsolstr.2008.07.021.

Schwaiger, R., Moser, B., Dao, M., Chollacoop, N. and Suresh, S., Some critical experiments on the strain-rate sensitivity of nanocrystalline nickel, Acta Materialia, Vol.51, No.17 (2003), pp.5159-5172, doi:10.1016/S1359-6454(03)00365-3.

Somekawa, H. and Mukai, T., Nanoindentation creep behavior of grain boundary in pure magnesium, Philosophical Magazine Letters, Vol.90, No.12 (2010), pp.883-890, doi:10.1080/09500839.2010.514577.

Srikant, G., Chollacoop, N. and Ramamurty, U., Plastic strain distribution underneath a vickers indenter: role of yield strength and work hardening exponent, Acta Materialia, Vol.54, No.19 (2006), pp.5171-5178, doi:10.1016/j.actamat.2006.06.032.

Tabor, D., The Physical meaning of indentation and scratch hardness, British Journal of Applied Physics, Vol.7 (1956), pp.159-166.

Taljat, B. and Pharr, G. M., Development of pile-up during spherical indentation of elastic- plastic solids, International Journal of Solids and Structures, Vol.41 (2004), pp.3891-3904, doi:10.1016/j.ijsolstr.2004.02.033.

Thomas, A. T., The tensile deformation behaviour of an aluminum-magnesium alloy, Acta Metallurgica, Vol.14 (1966), pp.1363-1374, doi:10.1017/CBO9781107415324.004.

Tirupataiah, Y. and Sundararajan, G., On the constraint factor associated with the indentation of work-hardening materials with a spherical ball, Vol.22 (1991), pp.2375-2384.

Wei, B.C., Zhang, L. C., Zhang, T.H., Xing, D.M., Das, J. and Eckert, J., Strain rate dependence of plastic flow in Ce-based bulk metallic glass during nanoindentation, Journal of Materials Research, Vol.22, No.2 (2007), pp.258-263, doi:10.1557/JMR.2007.0039.

Wood, J. and McCormick, P. G., Plastic flow instability in a precipitation hardened AlZnMg alloy, Acta Metallurgica, Vol.35, No.1 (1987), pp.247-251, doi:10.1016/0001-6160(87)90232-X.

Yamada, H., Hotta, M., Kami, T., Ogasawara, N. and Chen, X., Effect of dynamic strain rate on micro-indentation properties of pure aluminum, EPJ Web of Conferences, Vol.94 (2015), pp.04034.

Yamada, H., Ogasawara, N., Shimizu, Y., Horikawa, K., Kobayashi, H. and Chen, X., Effect of high strain rate on indentation in pure aluminum, Journal of Engineering Materials and Technology, Vol.135, No.2 (2013), pp.021010, doi:10.1115/1.4023778.

山田浩之, 清水陽子, 小笠原永久, Chen, X., 鋭い圧子で得られる荷重変位関係に及ぼすひずみ速度の影響, 実験 力学, Vol.12, No.2 (2012), pp.88-93. 


\section{References}

Alkorta, J., Martínez-Esnaola, J. M. and Sevillano, J. G., On the elastic effects in power-law indentation creep with sharp conical indenters, Journal of Materials Research, Vol.23, No.1 (2008), pp.182-188, doi:10.1557/JMR.2008.0011.

Balasundaram, A., Gokhale, A. M., Graham, S. and Horstemeyer, M. F., Three-dimensional particle cracking damage development in an Al-Mg-base wrought alloy, Materials Science and Engineering A, Vol.355, No.1-2 (2003), pp.368-383, doi:10.1016/S0921-5093(03)00103-5.

Bhakhri, V. and Klassen, R. J., Investigation of high-temperature plastic deformation using instrumented microindentation tests. part I the deformation of three aluminum alloys at $473 \mathrm{~K}$ to $833 \mathrm{~K}$, Journal of Materials Science, Vol.41 (2006), pp.2259-2270, doi:10.1007/s10853-006-7174-7.

Chen, X. and Vlassak, J. J., Numerical study on the measurement of thin film mechanical properties by means of nanoindentation, Journal of Materials Research, Vol.16, No.10 (2001), pp.2974-2982.

Cieslar, M., Fressengeas, C., Karimi, A. and Martin, J. L., Portevin-le chatelier effect in biaxially strained Al-Fe-Si foils, Scripta Materialia, Vol.48, No.8 (2003), pp.1105-1110, doi:10.1016/S1359-6462(02)00617-6.

Dao, M., Chollacoop, N., Van Vliet K. J., Venkatesh, T.A. and Suresh, S., Computational modeling of the forward and reverse problems in instrumented sharp indentation, Acta Materialia, Vol.49, No.19 (2001), pp.3899-3918, doi:10.1016/S1359-6454(01)00295-6.

Doerner, M. F. and Nix, W.D., A method for interpreting the data from depth-sensing indentation instruments, Journal of Materials Research, Vol.1, No.4 (1986), pp.601-609.

Estrin, Y., Kubin, L. P. and Aifantis, E. C., Introductory remarks to the viewpoint set on propagative plastic instabilities, Scripta Metallurgica et Materiala, Vol.29, No.9 (1993), pp.1147-1150, doi:10.1016/0956-716X(93)90100-7.

Fischer-Cripps, Anthony C., Introduction to contact mechanics, Springer (2007).

Fischer-Cripps, Anthony C., Nanoindentation, Springer (2011), doi:10.1007/978-1-4419-9872-9.

Ikeno, S., Urano, H., Uetani, Y. and Tada, S., Effect of aging treatment on serrated yield of Al-10\%Mg alloys, Journal of the Japan institute of light metals, Vol.38, No.8 (1988), pp.473-478(in Japanese).

Klassen, R. J., Diak, B. J. and Saimoto, S., Origin of the depth dependence of the apparent activation volume in polycrystalline $99.999 \% \mathrm{Cu}$ determined by displacement rate change micro-indentation, Materials Science and Engineering A, Vol.387-389 (2004), pp.297-301, doi:10.1016/j.msea.2004.02.079.

Li, M. and Lege, D.J., Serrated flow and surface markings in aluminum alloys, Journal of Engineering Materials and Technology, Vol.120, No.1 (1998), pp.48, doi:10.1115/1.2806837.

Liu, L., Ogasawara, N., Chiba, N. and Chen, X., Can indentation technique measure unique elastoplastic properties ?, Journal of Materials Research, Vol.24, No.3 (2008), pp.784-800, doi:10.1557/JMR.2009.0100.

Lucas, B. N. and Oliver, W. C., Indentation power-law creep of high-purity indium, Metallurgical and Materials Transactions A, Vol.30A (1999), pp.601-610.

Maier, V., Durst, K., Mueller, J., Backes, B., Höppel, H. and Göken, M, Nanoindentation strain-rate jump tests for determining the local strain-rate sensitivity in nanocrystalline $\mathrm{Ni}$ and ultrafine-grained $\mathrm{Al}$, Journal of Materials Research, Vol.26, No.11 (2011), pp.1421-1430, doi:10.1557/jmr.2011.156.

Mesarovic, S. D. and Fleck, N. A., Spherical indentation of elastic-plastic solids, Proceedings of the Royal Society London A, Vol.455 (1999), pp.2707-2728, doi:10.1098/rspa.1999.0423.

Moody, N.R., A, Strojny., Medlin, D., Gutherie, S. and Gerberich, W.W., Test rate effects on the mechanical behavior of thin aluminum films, Materials Research Society Symposium Proceedings, 522:281-286 (1998).

Nakamura, I., Indentation Hardness Test, Kogyo Chosakai Publishing Co., Ltd. (2007) (in Japanese).

Ogasawara, N., Chiba, N. and Chen, X., Representative strain of indentation analysis, Journal of Materials Research, Vol.20, No.08 (2005), pp.2225-2234, doi:10.1557/JMR.2005.0280.

Pan, D., Inoue, A., Sakurai, T. and Chen, M. W., Experimental characterization of shear transformation zones for plastic flow of bulk metallic glasses., Proceedings of the National Academy of Sciences of the United States of America, Vol.105, No.39 (2008), pp.14769-14772, doi:10.1073/pnas.0806051105.

Picu, R.C., Vincze, G., Ozturk, F., Gracio, J.J., Barlat, F. and Maniatty, A.M., Strain rate sensitivity of the commercial aluminum alloy AA5182-O, Materials Science and Engineering A, Vol.390 (2005), pp.334-343, doi:10.1016/j.msea.2004.08.029.

Pink, E. and Grinberg, A., Stress drops in serrated flow curves of Al5Mg, Acta Metallurgica, Vol.30, No.12 (1982), pp.2153-2160, doi:10.1016/0001-6160(82)90136-5.

Poisl, W.H., Oliver, W.C. and Fabes, B.D., The relationship between indentation and uniaxial creep in amorphous selenium, Journal of Materials Research, Vol.10, No.08 (1994), pp.2024-2032, doi:10.1557/JMR.1995.2024.

Poon, B., Rittel, D. and Ravichandran, G, An analysis of nanoindentation in linearly elastic solids, International Journal of Solids and Structures, Vol.45, No.24 (2008), pp.6018-6033, doi:10.1016/j.ijsolstr.2008.07.021.

Schwaiger, R., Moser, B., Dao, M., Chollacoop, N. and Suresh, S., Some critical experiments on the strain-rate sensitivity of nanocrystalline nickel, Acta Materialia, Vol.51, No.17 (2003), pp.5159-5172, doi:10.1016/S1359-6454(03)00365-3. 
Somekawa, H. and Mukai, T., Nanoindentation creep behavior of grain boundary in pure magnesium, Philosophical Magazine Letters, Vol.90, No.12 (2010), pp.883-890, doi:10.1080/09500839.2010.514577.

Srikant, G., Chollacoop, N. and Ramamurty, U., Plastic strain distribution underneath a vickers indenter: role of yield strength and work hardening exponent, Acta Materialia, Vol.54, No.19 (2006), pp.5171-5178, doi:10.1016/j.actamat.2006.06.032.

Tabor, D., The Physical meaning of indentation and scratch hardness, British Journal of Applied Physics, Vol.7 (1956), pp.159-166.

Taljat, B. and Pharr, G. M., Development of pile-up during spherical indentation of elastic- plastic solids, International Journal of Solids and Structures, Vol.41 (2004), pp.3891-3904, doi:10.1016/j.ijsolstr.2004.02.033.

Thomas, A. T., The tensile deformation behaviour of an aluminum-magnesium alloy, Acta Metallurgica, Vol.14 (1966), pp.1363-1374, doi:10.1017/CBO9781107415324.004.

Tirupataiah, Y. and Sundararajan, G., On the constraint factor associated with the indentation of work-hardening materials with a spherical ball, Vol.22 (1991), pp.2375-2384.

Wei, B.C., Zhang, L. C., Zhang, T.H., Xing, D.M., Das, J. and Eckert, J., Strain rate dependence of plastic flow in Ce-based bulk metallic glass during nanoindentation, Journal of Materials Research, Vol.22, No.2 (2007), pp.258-263, doi:10.1557/JMR.2007.0039.

Wood, J. and McCormick, P. G., Plastic flow instability in a precipitation hardened AlZnMg alloy, Acta Metallurgica, Vol.35, No.1 (1987), pp.247-251, doi:10.1016/0001-6160(87)90232-X.

Yamada, H., Hotta, M., Kami, T., Ogasawara, N. and Chen, X., Effect of dynamic strain rate on micro-indentation properties of pure aluminum, EPJ Web of Conferences, Vol.94 (2015), pp.04034.

Yamada, H., Ogasawara, N., Shimizu, Y., Horikawa, K., Kobayashi, H. and Chen, X., Effect of high strain rate on indentation in pure aluminum, Journal of Engineering Materials and Technology, Vol.135, No.2 (2013), pp.021010, doi:10.1115/1.4023778.

Yamada, H., Shimizu, Y.,Ogasawara, N. and Chen, X., Effect of strain rate on load-displacement relations by instrumented sharp indentation, Journal of the Japanese Society for Experimental Mechanics, Vol.12, No.2 (2012), pp.88-93(in Japanese). 

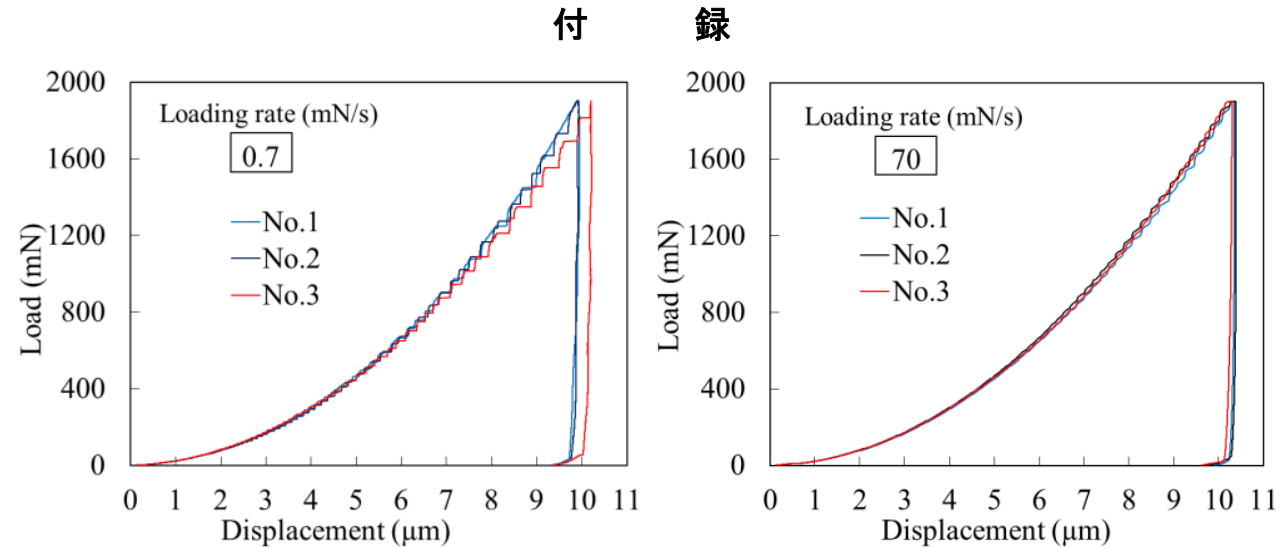

Appendix 1. Load-displacement relationship at loading rates of $0.7,70 \mathrm{mN} / \mathrm{s}$. The same degrees of serrated loads were reproducible for both loading rates.
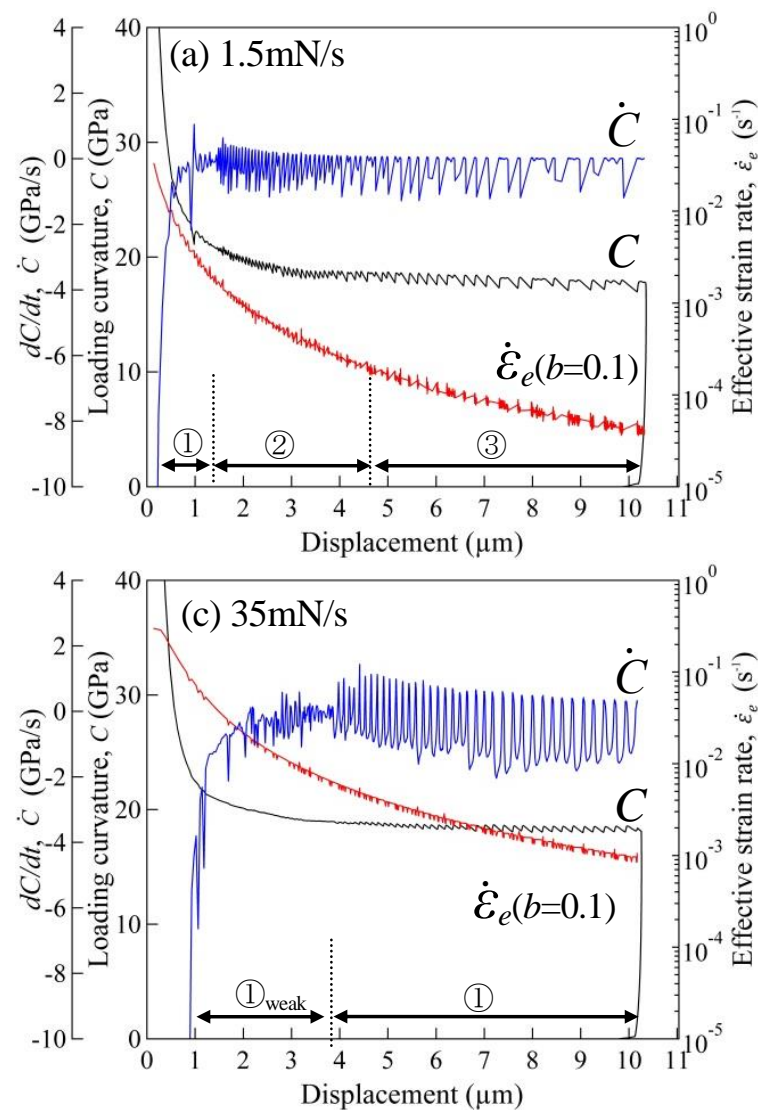
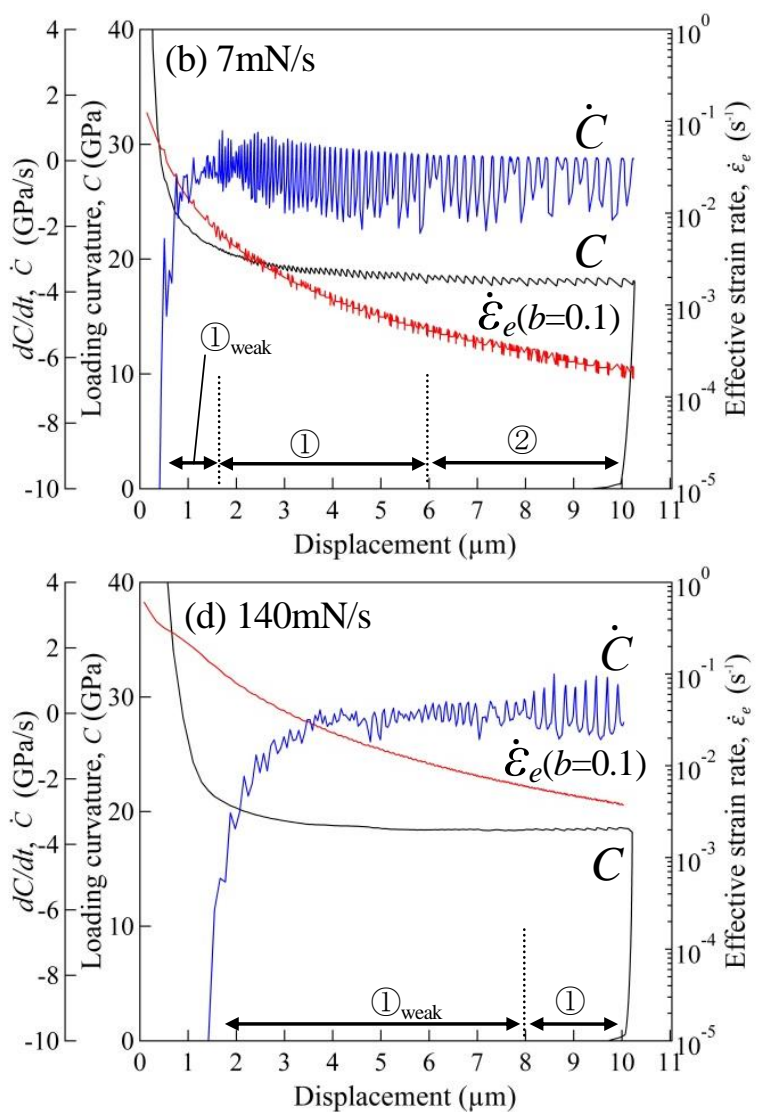

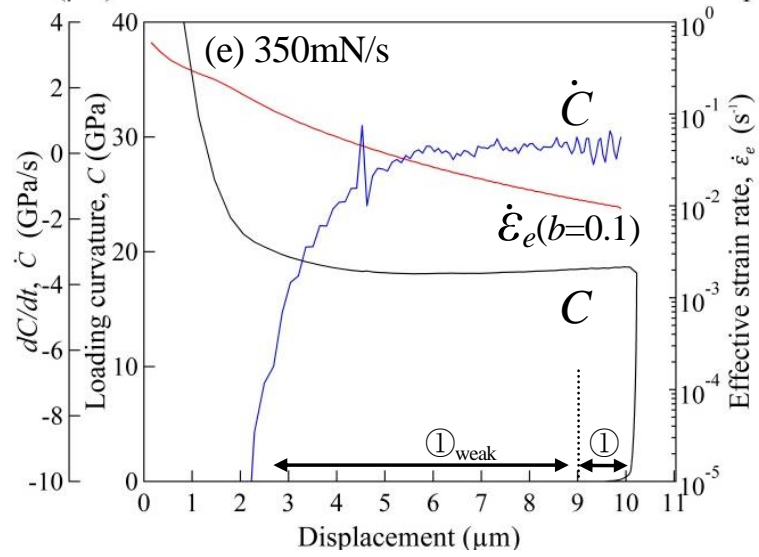

Appendix 2. Relationship between loading curvature and displacement with derivative of loading curvature and effective strain rate at different loading rates. Behavior of loading curvature changed as decreasing effective strain rate. 